\title{
A comparison of the accuracy of different types of samples for spatial structure indices determination in beech forests in Serbia
}

\author{
Bratislav Matović ${ }^{*}$, Dejan B. Stojanović1, Stefan Stjepanović², Marko Gutalj², Boban Miletić \\ 1 University of Novi Sad, Institute of Lowland Forestry and Environment, Novi Sad, Serbia \\ 2 University of East Sarajevo, Faculty of Agriculture, Istočno Sarajevo, Republic of Srpska (Bosnia and \\ Herzegovina) \\ * Corresponding author: Bratislav Matović; E-mail: bratislav.matovic@uns.ac.rs
}

Received: 22 Mar 2021; Revised: 6 Apr 2021; Accepted: 10 Apr 2021

\begin{abstract}
In this paper we compared the accuracy of different samples (minus the sample with the NN1 edge correction and buffer zone, plus sample and modified cluster sample) to determine indices of spatial structure in beech forests in Serbia, which can be used in regular forest inventory. The research was conducted in 11 forest stands of different structure at the territory of Central Serbia. Field data used for the assessment of spatial structure indices were collected across the examined stands on the sample plots of different sizes, using systematic grid, with the square layout of sample plots (100x100 meters). The study was conducted on 242 sample plots. For accuracy comparison of different sample types, five indices were used: Uniform angle index, Mean directional index, Species mingling index, DBH differentiation and DBH dominance indices. One-way ANOVA showed that at the stand level there were no statistically significant differences between mean values of indices obtained by different sample types. However, Simple linear correlations confirmed for most indices that if the spatial structure is to be determined with accuracy at the level of sample plots (in this case, a circular fixed radius plot of 5 acres) it is necessary to use a plus sample during data collection. For species mingling and DBH differentiation indices, Simple linear correlations show that both minus sampling with edge correction buffer zone and modified cluster sampling with somewhat less accuracy can be used to a certain extent. Minus sampling with NN1 edge correction is not practical for use on sample plots of this size in beech forests in Serbia.
\end{abstract}

Keywords: spatial structure, minus sample, plus sample, modified cluster sample, European beech, Serbia.

\section{Introduction}

Evaluation of stands spatial structure may provide a comprehensive information on the structure of stands, relative to the simple structure. Spatial structure of forest stands ensure detailed insight into their horizontal and vertical structure. Considering greater promotion of uneven-aged (Mlinšek, 1996; Gadow et al. 2002; Pommerening, Murphy, 2004; Matović et al. 2018a,b) and mixed forest stands (Bravo-Oviedo et al. 2014; Pretzsch et al. 2015) nowadays, knowledge on forest stands spatial structure 
becomes a necessary precondition for professional forest management. Gleichmar and Gerold (1998) believe that knowledge of the spatial structure, can be used to monitor the influence of the anthropogenic factor on the growth of forest stands.

The graphic illustration of trees in the horizontal plane is called the spatial pattern of trees and represents the basis for studying the spatial structure of forest stands (Tomppo, 1986). The three most important levels of spatial structure of forest, stand or sample plots according to Gadow (2005) are: diversity of tree positions, tree species diversity and diversity of tree dimensions. To quantify the spatial structure, a large number of parameters are used. In practice, the most commonly used classifications of indices and functions of spatial structure are: (a) single tree parameters based on neighbourhood relations to account for small-scale differences in forest structure, (b) distancedependent measure to describe forest structure at stand level, (c) continuous functions to describe forest structure by taking all possible inter-tree distances into account (Pommerrening, 2002).

For the assessment of spatial structure in different environmental research there are two different data collection strategies: mapping and sampling (Motz et al. 2010). Mapping implies a data collection of all individuals from the entire investigated area. In this case to quantify spatial structure, one can use indices, as well as various correlation function and second-order characteristics, along with different methods of spatial statistics (Dale, 1999). Sampling implies data collection for individuals only from a certain number of subsets, i.e. sample plots of small surface that are randomly or systematically distributed over the entire researched surface. In this case, indices can be used for the first-order quantification of the spatial structure.

Forest inventory is almost entirely based on sampling, because data is collected on large areas where mapping is not possible. For this reason, in practice, if data for the assessment of spatial structure are to be collected from a regular forest inventory, the indices of spatial structure can be used in first place. As in the collection of basic data in the regular forest inventory and in the assessment of spatial structure, one must pay special attention, in addition to the required accuracy, not to have too much expenses (Albert and Gadow, 1998).

In general, when it comes to the forest inventory in Europe, the mostly used are circular fixed radius plot, angle count (Bitterlich, 1984), concentric circles and distance sampling. Motz, et al. (2010) compared circular fixed radius plot sampling and angle count sampling for the assessment of spatial structure, and found that for almost all tested indices, better results were obtained using circular fixed radius plot sampling. Concentric circles sampling is complicated for data collection for the assessment of spatial structure. Distance sampling is often used in the assessment of spatial structure in various environmental studies (Krebs, 1999) but it is often a statistically biased sampling method (Motz, et al. 2010). Kint et al. (2004) found in a statistical-technical way that distance sampling, where the number of sample trees are randomly marked throughout a stand, is more accurate for the same size than the circular fixed radius plot sampling. However, such sampling is difficult to apply in forestry practice, especially in the application of the traditional forest inventory. Prodan's method of six nearest trees (Prodan, 1968), as a form of distance sampling used in the forest inventory, can also be used for the assessment of individual indices of spatial structure (Staupendahl, 2008), but its disadvantage is that it is of insufficient size for an accurate assessment of indices of spatial structure. From the distance sampling group, when it comes to the assessment of spatial structure, the sampling methods ",structural group of four" (Fueldner, 1995, 1996) and modified cluster sampling (see Hui and Albert, 2004) have also been proposed, yet they were not used in the forest inventory, but were primarily designed for the assessment of spatial structure. Hui and Albert, (2004) compared these two methods and found that modified cluster sampling is less biased in the first stage in indices describing the diversity of tree positions.

Considering that circular fixed radius plot is the most often used in regular forest inventory in Serbia, these sample plots are seemingly the most suitable for data collection for the assessment of spatial structure. However, when using circular fixed radius plot, where only trees are measured on a circle, as is the case with the forest inventory, the problem occurs with edge trees whose certain nearest neighbours are out of the circle. By neglecting these trees, a biased assessment of indices of spatial 
structure is obtained. In practice, this problem is most often solved by using plus sampling (more detailed description in the method of work) or minus sampling (more detailed description in the method of work) with the use of the so-called edge-correction. Clark and Evans (1954) and Pielou (1977) as the authors of the two most commonly used indices for the assessment of spatial structure in environmental research (aggregation index and coefficient of segregation) ignored the problem of the edge effect. Later and Donnelly (1978) developed an empirical edge-correction specifically for the aggregation index. To date, several edge-correction methods have been developed: reflection (Radtke, Burkhart, 1998), translation (Diggle, 2003), buffer zone (Diggle, 2003). For indices developed on the nearest neighbour concept, new methods NN1 and NN2 (Pommerening and Stoyan, 2006) developed on the basis set by Hanisch (1984), are also used for edge-correction. Pommerening and Stoyan (2006) found that edge-correction methods used in minus sampling (buffer zone, NN1 and NN2) were reliable on relatively large sample plots, but on small ones with a small number of individuals (less than 100 trees), biased assessments of indices of spatial structure were obtained. They suggest that plus sampling be used for small sample plots.

The aim of this research is to perform a comparison of the accuracy of different samples for determining indices of spatial structure in beech forest in Serbia, which in our opinion can be used in regular forest inventory.

\section{Material and methods}

In the territory of Central Serbia, 11 stands of different structure were selected, with the area of 10 to 32 hectares, taking care that the most important habitats where high monodominant beech forests occur were included. This meant that the sampling included stands of different: latitudes and longitudes, altitudes, exposures, terrain slopes, climate characteristics, phytocenoses, geological substrates and soils, etc. Stands were selected at nine sites where beech occurs as the dominant species (33a - Homoljske planine; 42a - Crni Vrh; 42b - Crni Vrh; 122a - Istočna Boranja; 27a - Zapadna Boranja; 31a - Čemernik-Ostrozub; 46a - Kukavica; 8a - Javor; 8b - Javor; 44a - Željin; 116a - Jastrebac) (more details about the localities and characteristics of stands in Matović, 2012).

Field data for the assessment of indices of spatial structure were collected in all examined stands on sample plots of different sizes using systematic sampling, with the square layout of sample plots (100x100 meters). The study was conducted on 242 sample plots. For the assessment of indices of spatial structure, three types of sampling were used, which in our opinion can be practically applied in regular forest inventory in beech forests in Serbia: minus sampling, plus sampling and modified cluster sampling. Sampling that is most adapted to the existing inventory in Serbia is minus sampling. In our case, it implies the diameter of trees located on a circular fixed radius sample plot of 5 ares, ignoring the real neighbours that are outside the sample plot (Figure 1).

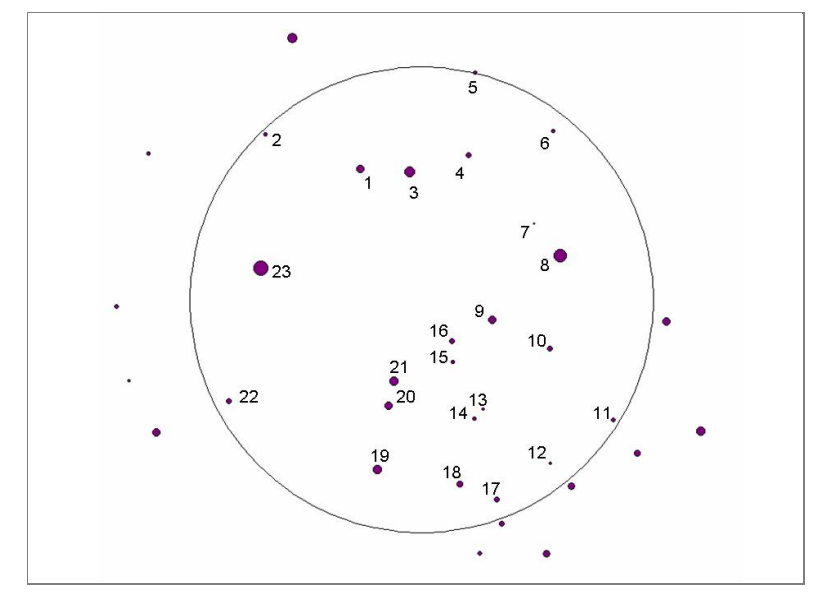

Figure 1. Example of minus sampling on the sample plot 19, stand 33a. Trees from 1 to 23 are measured. 
Using this sampling, the trees from the sample plot were determined: the type of trees, the trunk diameter of the tree, and the position of the trees on the sample plots (azimuth and the distance between the center of the sample plots and the trees on the sample plot). With this sampling, it is necessary to perform edge-correction in order to correct the values of the indices of spatial structure. Pommerening and Stoyan (2006) as stated above, found that biased assessments of indices of spatial structure were obtained on a small sample plot with a small number of individuals (less than 100 trees) and suggested the use of plus sampling. However, due to the wide application of this sampling in Serbia, we still tested the possibility of its application in practice. For this sampling, of the edge-correction methods, buffer zone (Diggle, 2003) and NN1 (Pommerening and Stoyan, 2006) were used.

The most accurate, but at the same time the most complicated and expensive solution is plus sampling (Stoyan and Stoyan, 1994; Gignoux, et al. 1999; Illian et al. 2008). Plus sampling means that in addition to measuring all trees from the sample plot, trees located on the periphery of the circular fixed radius sample plot have their real neighbours determined, including those outside the sample plot (Figure 2). Thus, in addition to the measuring, the minus sampling determines the position of the trees that are outside the sample plots which are the nearest neighbours of the trees from the sample plots (azimuth and the distance between the center of the sample plots and trees outside the sample plot). Also, for all additional trees, the type of trees and the trunk diameter were determined. Plus sampling has no error resulting from the edge effect, but requires additional measurements, which complicates and increases the cost of forest inventory. Lilleleht et al. (2014) suggest that in case of impossibility of data collection in this way, the method of reconstruction or conditional simulation outside the monitoring plot should be used.

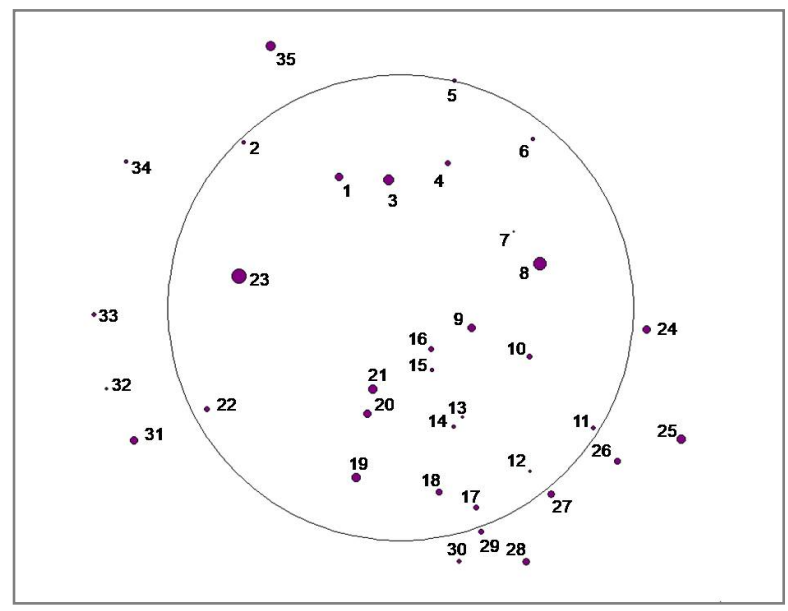

Figure 2. Example of plus sampling on the sample plot 19, stand 33a. In addition to trees from 1 to 23 , trees from 24 to 35 are also measured.

The most cost-efficient solution is modified cluster sampling (Hui and Albert, 2004), which is distance sampling and ignores the circular fixed radius sample plot (Figure 3). It is necessary to determine and measure the four reference trees closest to the center of the sample plot, and then to determine and measure the four nearest neighbours to each of the reference trees. This means that for all selected trees, the tree type, the trunk diameter and the tree position (azimuth and the distance between the center of the sample plot and selected trees) should be determined. This type of sampling also does not have an error resulting from the edge effect, but due to its size, it is more inaccurate compared to plus sampling.

Distance-dependent measure to describe forest structure at stand level and continuous functions to describe forest structure by taking all possible inter-tree distances into account are not totally suitable for the regular forest inventory, but they can rather be applied when experimental field of larger surface is used instead of sample plots. For this reason, only single tree parameters based on neighbourhood 
relations to account for small-scale differences in forest structure can be successfully used in forest inventory.

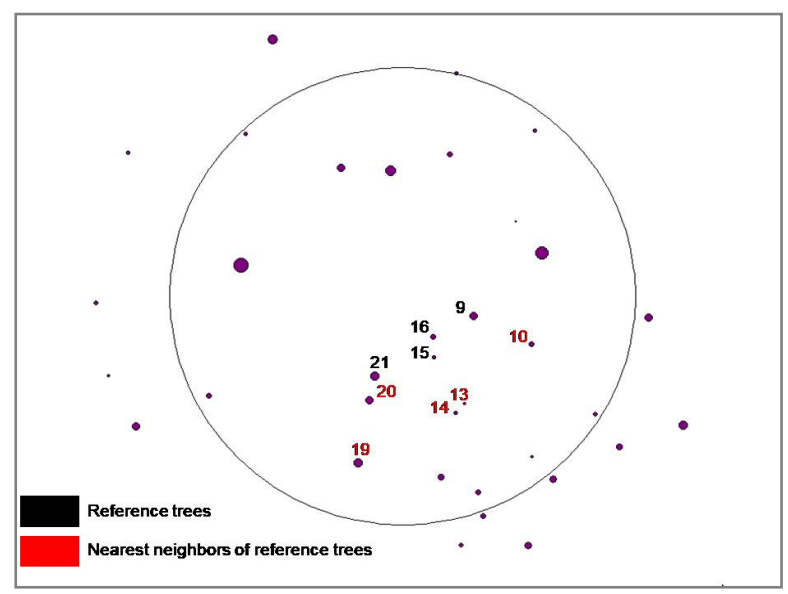

Figure 3. Example of modified cluster distance sampling on the circle 19, stand 33a. Trees 9, 15, 16 and 21 are measured (reference trees and nearest neighbours for certain trees), as well as 10,13, 14, 19 and 20 (nearest neighbours).

For the comparison of the accuracy of different sampling, five single tree parameters were used, based on neighbourhood relations, to account for small-scale differences in forest structure. Uniform angle index - W, (Gadow et al. 1998; Hui and Gadow, 2002) and Mean directional index - R (Corral Rivas, 2010) were used from the group of indices describing the diversity of tree positions. Species mingling - M (Fueldner, 1995, Pommerening, 2002) was used from the group of indices describing tree species diversity, while DBH differentiation - Td (Fueldner, 1995; Gadow, 1999; Pommerrening, 2002) and DBH dominance - Ud (Hui et al. 1998) were from the group of indices describing the diversity of tree dimensions.

The processing of spatial structure data was performed in a special Crancod (Pommerening, 2006a) application. For the comparison of the accuracy of different sampling for the assessment of indices of spatial structure, One-way ANOVA and Simple linear correlations were used.

\section{Results and discussion}

Values of indices were tested at the stand level and at the level of 209 sample plots. Namely, on a certain number of sample plots when using the edge-correction method NN1, it was not possible to calculate the values of certain indices, yet values of 0.00 were obtained (on 33 sample plots), which turned out to be a big disadvantage of this edge-correction method when using sample plots of a relatively small size. Despite the clear disadvantage of the use of the edge-correction method NN1, in order to be able to objectively compare all the sampling types applied in this research, the analysis was performed at the level of 209 instead of 242 sample plots. Significance of mean differences at the level of stands and at the level of 209 sample plots was determined by One-way ANOVA and LSD-test (Least Squares Difference), and the degree of compliance of indices obtained with different types of sampling on sample plots at the stand level and at the level of 209 sample plots was determined by Simple linear correlations.

One-way ANOVA shows that at the stand level there are no statistically significant mean differences in all five indices ( $\mathrm{W}, \mathrm{R}, \mathrm{M}, \mathrm{Td}$, and $\mathrm{Ud}$ ) obtained by different types of sampling. This is also confirmed by the LSD test, except that in Ud, in stands $8 \mathrm{~b}$ and 116a, there are significant differences between certain types of sampling (tables 1a and 1b). One-way ANOVA shows that at the level of 209 sample plots there are no statistically significant mean differences in all six indices obtained by different 
types of sampling, which is also confirmed by the LSD тест. The smallest mean differences were found in indices $M(p=0.98)$ and $T d(p=0.93)$, slightly larger in $W, R$, while the largest were found in $U d$.

As stated earlier, plus sampling $(+)$ is the most accurate because, on the one hand, it is the largest, and on the other hand, there is no error resulting from the edge effect. As such, it was further considered as the base sampling and it was compared to alternative samplings: modified cluster sampling (4X4), minus sampling with the edge-correction NN1 (NN1) and minus sampling with the edge-correction buffer zone (BZ). An analysis was performed which aimed to show which of the alternative samplings in most cases gave the mean results closest to the results obtained by base sampling, especially for all six indices, at the level of stands and at the level of 209 sample plots. For indices W, R, M, the best results were obtained by sampling BZ, while samplings $4 \mathrm{X} 4$ and NN1 are somewhat less accurate. For $\mathrm{Td}$, equal accuracy was obtained using samplings $4 \mathrm{X} 4, \mathrm{NN1}$ and $\mathrm{BZ}$, while for $\mathrm{Ud}$, the best results were obtained using sampling $4 \mathrm{X} 4$, and slightly unsatisfactory with samplings NN1 and BZ. Taking into account all stands (by analyzing tables $1 \mathrm{a}$ and $1 \mathrm{~b}$ ), sampling BZ in 25 cases gives the mean results closest to the base sampling, $4 \mathrm{X} 4$ in 17 and NN1 in 15 cases, while BZ gives the worst results in 14, $4 \mathrm{X} 4$ in 20 and NN1 in 21 cases.

Simple linear correlations aimed to show the compliance of the values of indices obtained by base plus sampling and indices obtained by samplings $4 \mathrm{X} 4$, NN1 and BZ on sample plots at the level of stands and at the level of 209 sample plots (tables $2 a$ and 2b). The correlation coefficient (r) and standard error of assessment $\left(\mathrm{S}_{\mathrm{e}}\right)$ were analyzed. For indices $\mathrm{W}, \mathrm{M}, \mathrm{Td}$ and $\mathrm{Ud}$, the strongest connection is between the base sampling and sampling BZ, while for samplings $4 \mathrm{X} 4$ and $\mathrm{NN} 1$, the connection is somewhat weaker. For index $R$, the strongest connection is between the base sampling and sampling $4 X 4$. Looking at all stands (by analyzing tables $2 \mathrm{a}$ and $2 \mathrm{~b}$ ), sampling BZ in 51 cases showed the greatest compliance of values of indices in relation to the base sampling (the indicated correlation coefficient and standard error of assessment), $4 \mathrm{X} 4$ in 36 and NN1 in 19 cases, while the least compliance BZ had in $11,4 \times 4$ in 36 , and NN1 in 60 cases.

However, a statistically strong correlation between the base sampling and other types of samplings at the level of 209 sample plots, was found only in indices $\mathrm{M}$ and $\mathrm{Td}$ ( $\mathrm{r}$ from 0.78 to 0.91 ). An example of the strong correlation between the Td base plus sampling and minus sampling with the edge-correction buffer zone (BZ) is shown in Figure $4(\mathrm{r}=0.85)$.

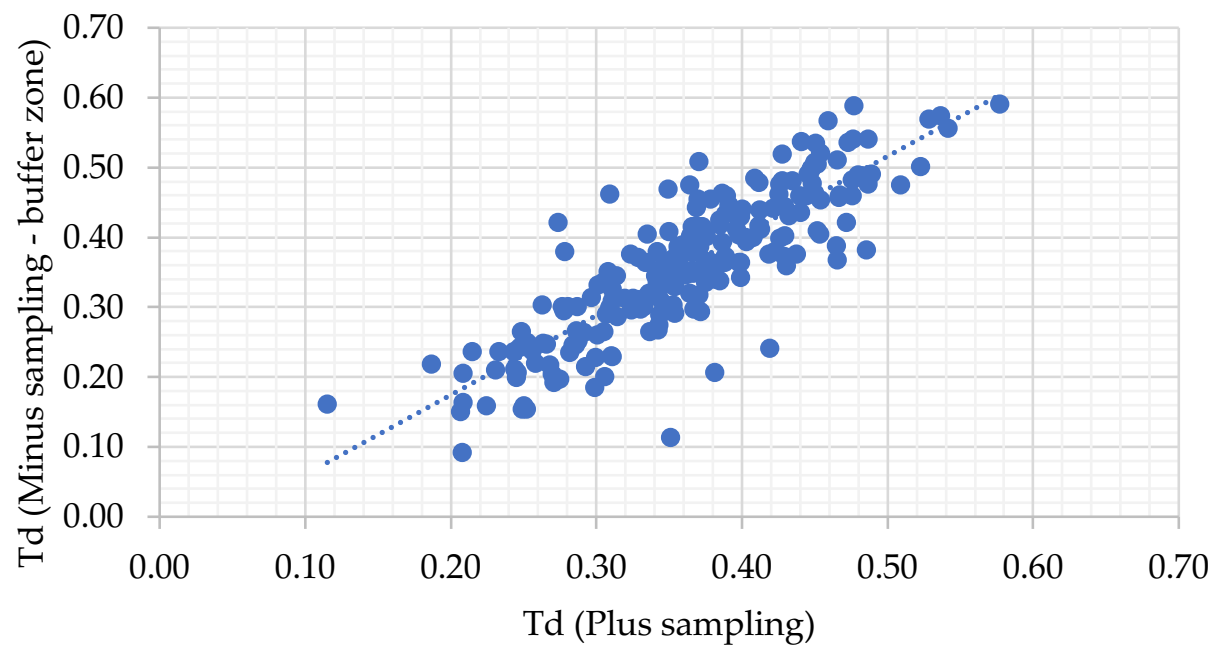

Figure 4. Correlation of $\mathrm{Td}$ plus sampling and minus sampling with the edge-correction buffer zone (BZ) at the level of 209 sample plots. 
Table 1a. One-way ANOVA at the level of stands 33a, 42a, 42b, 122a, 27a, 31a.

\begin{tabular}{|c|c|c|c|c|c|c|c|c|c|c|c|c|c|c|c|c|c|c|c|c|c|c|c|c|c|}
\hline \multirow{3}{*}{ Index } & \multirow{3}{*}{ ST } & \multicolumn{24}{|c|}{ Stand } \\
\hline & & \multicolumn{4}{|c|}{$33 a(n=23)$} & \multicolumn{4}{|c|}{$42 a(n=17)$} & \multicolumn{4}{|c|}{$42 b(n=10)$} & \multicolumn{4}{|c|}{$122 a(n=17)$} & \multicolumn{4}{|c|}{$27 a(n=20)$} & \multicolumn{4}{|c|}{$31 a(n=24)$} \\
\hline & & $\bar{X}$ & F & p & LSD & $\bar{X}$ & $\mathbf{F}$ & p & LSD & $\bar{X}$ & F & p & LSD & $\bar{X}$ & F & p & LSD & $\overline{\mathrm{X}}$ & $\mathbf{F}$ & p & $\begin{array}{c}\text { LS } \\
\text { D }\end{array}$ & $\overline{\mathrm{X}}$ & F & p & LSD \\
\hline \multirow{4}{*}{ W } & + & 0.48 & \multirow{4}{*}{1.06} & \multirow{4}{*}{0.37} & $x$ & 0.51 & \multirow{4}{*}{0.09} & \multirow{4}{*}{0.97} & $x$ & 0.49 & \multirow{4}{*}{0.22} & \multirow{4}{*}{0.88} & $\mathrm{x}$ & 0.51 & \multirow{4}{*}{0.40} & \multirow{4}{*}{0.75} & $x$ & 0.52 & \multirow{4}{*}{0.58} & \multirow{4}{*}{0.63} & $x$ & 0.52 & \multirow{4}{*}{0.28} & \multirow{4}{*}{0.84} & $x$ \\
\hline & $4 X 4$ & 0.46 & & & $x$ & 0.52 & & & $x$ & 0.53 & & & $x$ & 0.48 & & & $x$ & 0.51 & & & $x$ & 0.52 & & & $x$ \\
\hline & NN1 & 0.43 & & & $x$ & 0.52 & & & $x$ & 0.51 & & & $x$ & 0.49 & & & $x$ & 0.49 & & & $x$ & 0.52 & & & $x$ \\
\hline & $\mathrm{BZ}$ & 0.48 & & & $x$ & 0.50 & & & $x$ & 0.51 & & & $\mathrm{x}$ & 0.51 & & & $x$ & 0.50 & & & $\mathrm{x}$ & 0.53 & & & $\mathrm{x}$ \\
\hline \multirow{4}{*}{$\mathrm{R}$} & + & 1.68 & \multirow{4}{*}{1.12} & \multirow{4}{*}{0.35} & $x$ & 1.83 & & & $x$ & 1.71 & & & $x$ & 1.94 & & & $x$ & 1.84 & & & $x$ & 1.94 & & & $x$ \\
\hline & $4 \times 4$ & 1.68 & & & $x$ & 1.86 & 002 & 100 & $x$ & 1.88 & 030 & 082 & $\mathrm{x}$ & 1.78 & 0,53 & 067 & $\mathrm{x}$ & 1.76 & 0.48 & 070 & $x$ & 1.93 & 019 & (90. & $\mathrm{x}$ \\
\hline & NN1 & 1.51 & & & $x$ & 1.81 & 0.02 & 1.00 & $x$ & 1.81 & 0.30 & 0.82 & $\mathrm{x}$ & 1.82 & 0.53 & $0.0 /$ & $x$ & 1.66 & 0.48 & 0.70 & $\mathrm{x}$ & 1.92 & 0.19 & 0.90 & $x$ \\
\hline & $\mathrm{BZ}$ & 1.73 & & & $x$ & 1.83 & & & $x$ & 1.90 & & & $x$ & 1.91 & & & $x$ & 1.76 & & & $\mathrm{x}$ & 2.00 & & & $x$ \\
\hline & + & 0.07 & & & $x$ & 0.00 & & & $x$ & 0.03 & & & $x$ & 0.00 & & & $x$ & 0.00 & & & $x$ & 0.06 & & & $x$ \\
\hline $\mathrm{M}$ & $4 X 4$ & 0.08 & 0.02 & 1.00 & $x$ & 0.00 & & & $\mathrm{x}$ & 0.01 & 020 & 090 & $x$ & 0.00 & & & $x$ & 0.00 & & & $x$ & 0.05 & 003 & 099 & $x$ \\
\hline $\mathrm{M}$ & NN1 & 0.07 & 0.02 & 1.00 & $\mathrm{x}$ & 0.00 & & & $\mathrm{x}$ & 0.02 & 0.20 & 0.90 & $\mathrm{x}$ & 0.00 & & & $\mathrm{x}$ & 0.00 & & & $x$ & 0.05 & 0.03 & 0.99 & $x$ \\
\hline & $\mathrm{BZ}$ & 0.07 & & & $x$ & 0.00 & & & $x$ & 0.02 & & & $x$ & 0.00 & & & $x$ & 0.00 & & & $\mathrm{x}$ & 0.05 & & & $x$ \\
\hline & + & 0.37 & & & $x$ & 0.34 & & & $x$ & 0.38 & & & $x$ & 0.37 & & & $x$ & 0.39 & & & $x$ & 0.33 & & & $x$ \\
\hline & $4 \times 4$ & 0.38 & & & $x$ & 0.32 & & & $x$ & 0.36 & & & $x$ & 0.40 & & & $x$ & 0.39 & & & $x$ & 0.32 & & & $x$ \\
\hline $\mathrm{Td}$ & NN1 & 0.37 & 0.02 & 1.00 & $x$ & 0.31 & 0.18 & 0.91 & $x$ & 0.39 & 0.31 & 0.82 & $x$ & 0.38 & 0.43 & 0.74 & $x$ & 0.38 & 0.11 & 0.95 & $x$ & 0.32 & 0.05 & 0.98 & $x$ \\
\hline & $\mathrm{BZ}$ & 0.37 & & & $x$ & 0.33 & & & $x$ & 0.40 & & & $x$ & 0.38 & & & $x$ & 0.39 & & & $x$ & 0.32 & & & $x$ \\
\hline & + & 0.48 & & & $x$ & 0.49 & & & $x$ & 0.47 & & & $x$ & 0.48 & & & $x$ & 0.49 & & & $x$ & 0.49 & & & $x$ \\
\hline & $4 \times 4$ & 0.49 & & & $x$ & 0.47 & & & $x$ & 0.51 & & & $x$ & 0.52 & & & $x$ & 0.48 & & & $x$ & 0.50 & & & $x$ \\
\hline Ud & NN1 & 0.48 & 0.26 & 0.85 & $x$ & 0.42 & 1.07 & 0.37 & $x$ & 0.49 & 0.33 & 0.80 & $x$ & 0.53 & 0.40 & 0.75 & $x$ & 0.46 & 0.63 & 0.60 & $x$ & 0.51 & 1.14 & 0.34 & $x$ \\
\hline & $\mathrm{BZ}$ & 0.45 & & & $x$ & 0.47 & & & $\mathrm{x}$ & 0.46 & & & $x$ & 0.49 & & & $x$ & 0.44 & & & $\mathrm{x}$ & 0.44 & & & $x$ \\
\hline
\end{tabular}

Legend: ST - sampling type. 
Table 1b. One-way ANOVA at the level of stands 46a, 8a, 8b, 44a, 116a and at the level of 209 sample plots.

\begin{tabular}{|c|c|c|c|c|c|c|c|c|c|c|c|c|c|c|c|c|c|c|c|c|c|c|c|c|c|}
\hline \multirow{3}{*}{ Index } & \multirow{3}{*}{ ST } & \multicolumn{24}{|c|}{ Stand } \\
\hline & & \multicolumn{4}{|c|}{$46 a(n=24)$} & \multicolumn{4}{|c|}{$8 a(n=15)$} & \multicolumn{4}{|c|}{$8 b(n=10)$} & \multicolumn{4}{|c|}{$44 a(n=19)$} & \multicolumn{4}{|c|}{ 116a $(n=30)$} & \multicolumn{4}{|c|}{ Total $(n=209)$} \\
\hline & & $\bar{X}$ & $\mathbf{F}$ & $\mathrm{p}$ & LSD & $\bar{X}$ & $\mathbf{F}$ & $\mathbf{p}$ & LSD & $\bar{X}$ & $\mathbf{F}$ & $\mathbf{p}$ & LSD & $\bar{X}$ & $\mathbf{F}$ & $\mathrm{p}$ & LSD & $\bar{X}$ & $\mathbf{F}$ & $\mathbf{p}$ & LSD & $\bar{X}$ & $\mathbf{F}$ & $\mathbf{p}$ & LSD \\
\hline \multirow{4}{*}{ W } & + & 0.53 & \multirow{4}{*}{0.18} & \multirow{4}{*}{0.91} & $x$ & 0.50 & \multirow{4}{*}{0.29} & \multirow{4}{*}{0.83} & $x$ & 0.51 & \multirow{4}{*}{0.22} & \multirow{4}{*}{0.88} & $x$ & 0.52 & \multirow{4}{*}{0.47} & \multirow{4}{*}{0.70} & $x$ & 0.54 & \multirow{4}{*}{0.32} & \multirow{4}{*}{0.81} & $\mathrm{x}$ & 0.51 & \multirow{4}{*}{0.23} & \multirow{4}{*}{0.88} & $\mathrm{x}$ \\
\hline & $4 \times 4$ & 0.52 & & & $\mathrm{x}$ & 0.50 & & & $x$ & 0.54 & & & $\mathrm{x}$ & 0.50 & & & $\mathrm{x}$ & 0.53 & & & $x$ & 0.51 & & & $\mathrm{x}$ \\
\hline & NN1 & 0.54 & & & $x$ & 0.52 & & & $x$ & 0.53 & & & $x$ & 0.53 & & & $x$ & 0.53 & & & $x$ & 0.51 & & & $x$ \\
\hline & $\mathrm{BZ}$ & 0.53 & & & $\mathrm{x}$ & 0.49 & & & $\mathrm{x}$ & 0.53 & & & $\mathrm{x}$ & 0.52 & & & $\mathrm{x}$ & 0.52 & & & $x$ & 0.51 & & & $x$ \\
\hline \multirow{4}{*}{$\mathrm{R}$} & + & 1.94 & \multirow{4}{*}{0.10} & \multirow{4}{*}{0.96} & $x$ & 1.77 & & & $x$ & 1.88 & & & $x$ & 1.90 & & & $x$ & 2.10 & & & $x$ & 1.89 & & & $x$ \\
\hline & $4 \times 4$ & 1.93 & & & $x$ & 1.72 & & & $x$ & 2.18 & & & $\mathrm{x}$ & 1.73 & & & $x$ & 2.05 & & & $x$ & 1.86 & & & $x$ \\
\hline & NN1 & 2.00 & & & $x$ & 1.83 & 0.23 & 0.88 & $x$ & 1.99 & 1.18 & 0.33 & $x$ & 1.78 & 0.73 & 0.54 & $x$ & 2.06 & 0.65 & 0.59 & $x$ & 1.84 & 0.41 & 0.75 & $x$ \\
\hline & $\mathrm{BZ}$ & 1.94 & & & $x$ & 1.68 & & & $x$ & 1.95 & & & $x$ & 1.91 & & & $x$ & 1.98 & & & $x$ & 1.88 & & & $x$ \\
\hline & + & 0.03 & & & $x$ & 0.00 & & & $x$ & 0.00 & & & $x$ & 0.01 & & & $x$ & 0.19 & & & $x$ & 0.05 & & & $x$ \\
\hline M & $4 X 4$ & 0.02 & 0.02 & 100 & $x$ & 0.00 & & & $x$ & 0.00 & & & $x$ & 0.01 & 0.20 & & $x$ & 0.19 & & & $x$ & 0.04 & & & $x$ \\
\hline $\mathrm{M}$ & NN1 & 0.03 & 0.02 & 1.00 & $\mathrm{x}$ & 0.00 & & & $\mathrm{x}$ & 0.00 & & & $\mathrm{x}$ & 0.03 & 0.20 & 0.90 & $x$ & 0.15 & 0.18 & 0.91 & $x$ & 0.04 & 0.06 & 0.98 & $x$ \\
\hline & $\mathrm{BZ}$ & 0.03 & & & $x$ & 0.00 & & & $x$ & 0.00 & & & $x$ & 0.01 & & & $x$ & 0.19 & & & $x$ & 0.05 & & & $x$ \\
\hline & + & 0.38 & & & $x$ & 0.26 & & & $x$ & 0.37 & & & $x$ & 0.42 & & & $x$ & 0.37 & & & $x$ & 0.36 & & & $x$ \\
\hline $\mathrm{Td}$ & $4 \mathrm{X} 4$ & 0.39 & 012 & 095 & $x$ & 0.25 & 0.45 & 072 & $x$ & 0.38 & 022 & 088 & $x$ & 0.40 & 015 & 0.93 & $x$ & 0.38 & 0.11 & 0.95 & $x$ & 0.36 & 014 & 0.93 & $x$ \\
\hline Ia & NN1 & 0.38 & 0.12 & 0.90 & $x$ & 0.24 & 0.45 & 0.72 & $x$ & 0.38 & 0.22 & 0.88 & $x$ & 0.42 & 0.15 & 0.93 & $x$ & 0.37 & 0.11 & 0.90 & $x$ & 0.36 & 0.14 & 0.93 & $x$ \\
\hline & $\mathrm{BZ}$ & 0.38 & & & $x$ & 0.24 & & & $x$ & 0.39 & & & $x$ & 0.40 & & & $x$ & 0.37 & & & $x$ & 0.36 & & & $x$ \\
\hline & + & 0.49 & & & $x$ & 0.48 & & & $x$ & 0.50 & & & $x$ & 0.49 & & & $x$ & 0.50 & & & $x x$ & 0.49 & & & $x$ \\
\hline Ud & $4 X 4$ & 0.49 & 0.15 & 0.93 & $x$ & 0.49 & 0.88 & 0.43 & $x$ & 0.40 & 214 & 011 & $x$ & 0.49 & 012 & 095 & $x$ & 0.52 & 173 & 016 & $x$ & 0.49 & 193 & 012 & $x$ \\
\hline Ud & NN1 & 0.47 & 0.15 & 0.93 & $x$ & 0.43 & 0.88 & 0.43 & $x$ & 0.47 & 2.14 & 0.11 & $x x$ & 0.47 & 0.12 & 0.90 & $x$ & 0.45 & 1.10 & 0.10 & $x$ & 0.47 & 1.90 & 0.12 & $x$ \\
\hline & BZ & 0.46 & & & $\mathrm{x}$ & 0.49 & & & $\mathrm{x}$ & 0.46 & & & $x x$ & 0.47 & & & $\mathrm{x}$ & 0.48 & & & $x x$ & 0.47 & & & $x$ \\
\hline
\end{tabular}

Legend: ST - sampling type. 
Table 2a. Simple linear correlations at the level of stands 33a, 42a, 42b, 122a, 27a, 31a.

\begin{tabular}{|c|c|c|c|c|c|c|c|c|c|c|c|c|c|c|c|c|c|c|c|c|c|c|c|c|c|}
\hline \multirow{3}{*}{ Index } & \multirow{3}{*}{ ST } & \multicolumn{24}{|c|}{ Stand } \\
\hline & & \multicolumn{4}{|c|}{$33 a(n=23)$} & \multicolumn{4}{|c|}{$42 a(n=17)$} & \multicolumn{4}{|c|}{$42 b(n=10)$} & \multicolumn{4}{|c|}{$122 a(n=17)$} & \multicolumn{4}{|c|}{$27 a(n=20)$} & \multicolumn{4}{|c|}{$31 a(n=24)$} \\
\hline & & $\mathbf{r}$ & Se & $F$ & $p$ & $\mathbf{r}$ & Se & $F$ & $p$ & $\mathbf{r}$ & Se & $F$ & $p$ & $\mathbf{r}$ & Se & $\mathbf{F}$ & $p$ & $\mathbf{r}$ & Se & $F$ & $p$ & $\mathbf{r}$ & Se & $F$ & $\mathrm{p}$ \\
\hline \multirow{3}{*}{ W } & $+/ 4 \times 4$ & 0.57 & 0.10 & 10.0 & 0.01 & 0.38 & 0.12 & 2.61 & 0.13 & 0.92 & 0.05 & 43.75 & 0.00 & 0.73 & 0.07 & 17.16 & 0.00 & 0.63 & 0.06 & 11.77 & 0.00 & 0.71 & 0.06 & 22.25 & 0.00 \\
\hline & +/NN1 & 0.24 & 0.15 & 1.31 & 0.27 & 0.52 & 0.08 & 5.54 & 0.03 & 0.77 & 0.08 & 11.50 & 0.01 & 0.69 & 0.09 & 13.67 & 0.00 & 0.45 & 0.11 & 4.67 & 0.04 & 0.37 & 0.08 & 3.45 & 0.08 \\
\hline & $+/ \mathrm{BZ}$ & 0.36 & 0.09 & 3.2 & 0.09 & 0.52 & 0.10 & 5.47 & 0.03 & 0.82 & 0.05 & 16.93 & 0.00 & 0.35 & 0.08 & 2.06 & 0.17 & 0.52 & 0.08 & 6.65 & 0.02 & 0.39 & 0.07 & 3.95 & 0.06 \\
\hline \multirow{3}{*}{$\mathrm{R}$} & $+/ 4 \times 4$ & 0.58 & 0.36 & 10.4 & 0.00 & 0.75 & 0.43 & 19.25 & 0.00 & 0.91 & 0.26 & 36.96 & 0.00 & 0.57 & 0.40 & 7.39 & 0.02 & 0.73 & 0.28 & 2.076 & 0.00 & 0.64 & 0.34 & 14.90 & 0.00 \\
\hline & $+/ \mathrm{NN} 1$ & 0.36 & 0.61 & 3.0 & 0.10 & 0.70 & 0.52 & 14.51 & 0.00 & 0.77 & 0.41 & 11.73 & 0.01 & 0.43 & 0.47 & 3.37 & 0.09 & 0.65 & 0.50 & 13.01 & 0.00 & 0.77 & 0.31 & 32.99 & 0.00 \\
\hline & $+/ \mathrm{BZ}$ & 0.38 & 0.38 & 3.5 & 0.08 & 0.66 & 0.43 & 11.31 & 0.00 & 0.81 & 0.23 & 15.63 & 0.00 & 0.38 & 0.34 & 2.56 & 0.13 & 0.65 & 0.38 & 13.28 & 0.00 & 0.25 & 0.40 & 1.49 & 0.04 \\
\hline \multirow{3}{*}{ M } & $+/ 4 \times 4$ & 0.95 & 0.07 & 211.9 & 0.00 & - & - & - & - & - & - & - & - & - & - & - & - & - & - & - & - & 0.87 & 0.07 & 65.81 & 0.00 \\
\hline & $+/ \mathrm{NN} 1$ & 0.89 & 0.09 & 82.5 & 0.00 & - & - & - & - & - & - & - & - & - & - & - & - & - & - & - & - & 0.68 & 0.12 & 18.78 & 0.00 \\
\hline & $+/ \mathrm{BZ}$ & 0.96 & 0.05 & 261.4 & 0.00 & - & - & - & - & - & - & - & - & - & - & - & - & - & - & - & - & 0.81 & 0.09 & 42.32 & 0.00 \\
\hline \multirow[b]{3}{*}{$\mathrm{Td}$} & $+/ 4 \times 4$ & 0.81 & 0.05 & 41.5 & 0.00 & 0.74 & 0.08 & 17.64 & 0.00 & 0.76 & 0.07 & 11.11 & 0.00 & 0.67 & 0.08 & 12.07 & 0.00 & 0.68 & 0.07 & 15.77 & 0.00 & 0.86 & 0.06 & 60.45 & 0.00 \\
\hline & $+/ \mathrm{NN} 1$ & 0.86 & 0.07 & 59.2 & 0.00 & 0.77 & 0.08 & 21.84 & 0.00 & 0.84 & 0.05 & 18.70 & 0.00 & 0.78 & 0.07 & 23.16 & 0.00 & 0.67 & 0.08 & 14.81 & 0.00 & 0.78 & 0.07 & 34.75 & 0.00 \\
\hline & $+/ \mathrm{BZ}$ & 0.88 & 0.05 & 72.5 & 0.00 & 0.89 & 0.05 & 54.98 & 0.00 & 0.91 & 0.04 & 40.20 & 0.00 & 0.82 & 0.06 & 29.80 & 0.00 & 0.86 & 0.04 & 49.56 & 0.00 & 0.90 & 0.05 & 92.40 & 0.00 \\
\hline \multirow{3}{*}{ Ud } & $+/ 4 \times 4$ & 0.10 & 0.13 & 0.19 & 0.66 & 0.59 & 0.11 & 8.08 & 0.01 & 0.08 & 0.13 & 0.05 & 0.82 & 0.01 & 0.11 & 0.06 & 0.81 & 0.01 & 0.09 & 0.00 & 0.98 & 0.00 & 0.10 & 0.00 & 0.99 \\
\hline & $+/ \mathrm{NN} 1$ & 0.12 & 0.17 & 0.33 & 0.57 & 0.16 & 0.15 & 0.41 & 0.53 & 0.37 & 0.18 & 1.25 & 0.30 & 0.13 & 0.20 & 0.27 & 0.61 & 0.03 & 0.21 & 0.01 & 0.91 & 0.38 & 0.22 & 3.68 & 0.07 \\
\hline & $+/ \mathrm{BZ}$ & 0.10 & 0.17 & 0.20 & 0.66 & 0.27 & 0.11 & 1.17 & 0.30 & 0.53 & 0.04 & 3.17 & 0.11 & 0.22 & 0.17 & 0.79 & 0.39 & 0.13 & 0.09 & 0.30 & 0.59 & 0.27 & 0.09 & 1.66 & 0.21 \\
\hline
\end{tabular}

Legend: ST - sampling type. 
Table $2 \mathbf{b}$. Simple linear correlations at the level of stands 46a, 8a, 8b, 44a, 116a and at the level of 209 sample plots.

\begin{tabular}{|c|c|c|c|c|c|c|c|c|c|c|c|c|c|c|c|c|c|c|c|c|c|c|c|c|c|}
\hline \multirow{3}{*}{ Index } & \multirow{3}{*}{ ST } & \multicolumn{24}{|c|}{ Stand } \\
\hline & & \multicolumn{4}{|c|}{$46 a(n=24)$} & \multicolumn{4}{|c|}{$8 a(n=15)$} & \multicolumn{4}{|c|}{$8 b(n=10)$} & \multicolumn{4}{|c|}{$44 a(n=19)$} & \multicolumn{4}{|c|}{$116 a(n=30)$} & \multicolumn{4}{|c|}{ Total $(n=209)$} \\
\hline & & $\mathbf{r}$ & Se & $\mathbf{F}$ & p & $\mathbf{r}$ & Se & $\mathbf{F}$ & p & $\mathbf{r}$ & Se & $\mathbf{F}$ & p & $\mathbf{r}$ & Se & $\mathbf{F}$ & p & $\mathbf{r}$ & Se & $\mathbf{F}$ & p & $\mathbf{r}$ & Se & $\mathbf{F}$ & p \\
\hline \multirow{3}{*}{ W } & $+/ 4 \times 4$ & 0.54 & 0.08 & 9.08 & 0.01 & 0.45 & 0.09 & 3.25 & 0.09 & 0.18 & 0.10 & 0.28 & 0.61 & 0.23 & 0.08 & 0.95 & 0.34 & 0.30 & 0.08 & 2.78 & 0.11 & 0.53 & 0.08 & 79.51 & 0.00 \\
\hline & +/NN1 & 0.55 & 0.12 & 9.46 & 0.01 & 0.57 & 0.09 & 6.23 & 0.03 & 0.27 & 0.05 & 0.64 & 0.45 & 0.34 & 0.12 & 2.29 & 0.15 & 0.25 & 0.12 & 1.95 & 0.17 & 0.46 & 0.11 & 56.22 & 0.00 \\
\hline & $+/ \mathrm{BZ}$ & 0.66 & 0.06 & 16.75 & 0.00 & 0.55 & 0.06 & 5.74 & 0.03 & 0.29 & 0.07 & 0.71 & 0.42 & 0.52 & 0.09 & 6.28 & 0.02 & 0.35 & 0.06 & 3.88 & 0.06 & 0.47 & 0.07 & 59.36 & 0.00 \\
\hline \multirow{3}{*}{$\mathrm{R}$} & $+/ 4 \times 4$ & 0.63 & 0.37 & 14.27 & 0.00 & 0.74 & 0.40 & 15.50 & 0.00 & 0.17 & 0.53 & 0.23 & 0.65 & 0.57 & 0.38 & 8.32 & 0.01 & 0.00 & 0.27 & 0.00 & 1.00 & 0.61 & 0.38 & 119.8 & 0.00 \\
\hline & $+/ \mathrm{NN} 1$ & 0.61 & 0.48 & 13.15 & 0.00 & 0.63 & 0.51 & 8.74 & 0.01 & 0.26 & 0.35 & 0.58 & 0.47 & 0.63 & 0.47 & 10.92 & 0.00 & 0.20 & 0.54 & 1.20 & 0.28 & 0.58 & 0.48 & 106.3 & 0.00 \\
\hline & $+/ \mathrm{BZ}$ & 0.57 & 0.38 & 10.65 & 0.00 & 0.46 & 0.42 & 3.50 & 0.08 & 0.33 & 0.35 & 0.99 & 0.35 & 0.79 & 0.34 & 27.45 & 0.00 & 0.16 & 0.31 & 0.76 & 0.39 & 0.52 & 0.37 & 78.27 & 0.00 \\
\hline \multirow{3}{*}{ M } & $+/ 4 \times 4$ & 0.48 & 0.08 & 6.74 & 0.02 & - & - & - & - & - & - & - & - & - & - & - & - & 0.88 & 0.11 & 101.0 & 0.00 & 0.89 & 0.06 & 790.5 & 0.00 \\
\hline & $+/ \mathrm{NN} 1$ & 0.71 & 0.06 & 23.00 & 0.00 & - & - & - & - & - & - & - & - & - & - & - & - & 0.88 & 0.11 & 93.72 & 0.00 & 0.85 & 0.07 & 543.2 & 0.00 \\
\hline & $+/ \mathrm{BZ}$ & 0.65 & 0.06 & 16.40 & 0.00 & - & - & - & - & - & - & - & - & - & - & - & - & 0.91 & 0.10 & 129.8 & 0.00 & 0.91 & 0.06 & 1047 & 0.00 \\
\hline \multirow{3}{*}{$\mathrm{Td}$} & $+/ 4 \times 4$ & 0.77 & 0.07 & 32.65 & 0.00 & 0.61 & 0.05 & 7.71 & 0.02 & 0.56 & 0.07 & 3.77 & 0.09 & 0.74 & 0.08 & 21.02 & 0.00 & 0.76 & 0.07 & 37.99 & 0.00 & 0.78 & 0.07 & 321.8 & 0.00 \\
\hline & $+/ \mathrm{NN} 1$ & 0.65 & 0.10 & 16.10 & 0.00 & 0.66 & 0.07 & 10.26 & 0.01 & 0.73 & 0.05 & 9.16 & 0.02 & 0.66 & 0.10 & 13.25 & 0.00 & 0.84 & 0.07 & 69.41 & 0.00 & 0.79 & 0.07 & 336.1 & 0.00 \\
\hline & $+/ \mathrm{BZ}$ & 0.68 & 0.08 & 18.62 & 0.00 & 0.64 & 0.05 & 9.25 & 0.01 & 0.60 & 0.05 & 6.35 & 0.04 & 0.81 & 0.07 & 32.37 & 0.00 & 0.84 & 0.06 & 67.06 & 0.00 & 0.85 & 0.06 & 528.8 & 0.00 \\
\hline \multirow{3}{*}{ Ud } & $+/ 4 \times 4$ & 0.31 & 0.12 & 2.27 & 0.15 & 0.51 & 0.14 & 4.59 & 0.05 & 0.40 & 0.13 & 1.50 & 0.26 & 0.18 & 0.10 & 0.59 & 0.45 & 0.13 & 0.12 & 0.45 & 0.51 & 0.18 & 0.12 & 6.66 & 0.01 \\
\hline & $+/ \mathrm{NN} 1$ & 0.53 & 0.20 & 8.82 & 0.01 & 0.02 & 0.11 & 0.01 & 0.94 & 0.17 & 0.08 & 0.23 & 0.64 & 0.03 & 0.21 & 0.02 & 0.89 & 0.44 & 0.17 & 6.61 & 0.02 & 0.10 & 0.19 & 1.98 & 0.16 \\
\hline & $+/ \mathrm{BZ}$ & 0.45 & 0.13 & 5.51 & 0.03 & 0.50 & 0.12 & 4.33 & 0.06 & 0.63 & 0.08 & 5.25 & 0.05 & 0.17 & 0.09 & 0.52 & 0.48 & 0.06 & 0.09 & 0.10 & 0.76 & 0.17 & 0.12 & 5.99 & 0.02 \\
\hline
\end{tabular}

Legend: ST - sampling type. 
Even with such a strong correlation, it can be noticed that the deviation on certain sample plots is large. With indices $\mathrm{W}, \mathrm{R}$ (indices describing the diversity of tree positions), they are slightly weaker ( $\mathrm{r}$ from 0.46 to 0.61 ). Index $\mathrm{Ud}$ is characterized by a very weak connection ( $\mathrm{r}$ from 0.10 to 0.18 ) and this index cannot be even approximately assessed using alternative samplings (4X4, NN1 and BZ). Other authors found that at the same sampling size, indices describing the tree species diversity and the diversity of tree dimensions can be assessed with greater accuracy, compared to indices describing the diversity of tree positions (Lohl et al. 1994; Hui and Albert, 2004). Kint et al. (2004) found that for the same accuracy, a maximum sample size is required for the assessment of indices describing the diversity of tree positions, while for the assessment of indices describing the tree species diversity and the diversity of tree dimensions, the sample size is smaller.

The main question that can be asked when researching a spatial structure with the method of partial survey, i.e. sampling (used in this study), is whether a spatial structure of a stand or some larger unit as a whole can be reliably assessed based on the determination of the spatial structure on small sample plots. This problem was studied using different simulation models for spatial structure reconstruction and it was confirmed that the spatial structure determined on small sample plots could be successfully reconstructed for entire stands or larger areas (Pretzsch, 1997; Lewandowski and Gadow, 1997; Pommerening, 2000; Biber, 1999; Pommerening and Stoyan, 2008).

Pommerening and Stoyan (2008) investigated the possibility of reconstructing the spatial structure of three stands from Poland, Hungary and Germany, which differed greatly in their structural characteristics. They used circles with a constant diameter of a similar size as in our study, and simulated 1000 repetitions in each stand. They found that the spatial structure of stands could be reliably reconstructed on the basis of the determined spatial structure of sample plots of standard sizes used in forest inventories in Europe. Lilleleht et al. (2014) found that in small sample plots, the reconstruction method was reliable for edge-bias mitigation has and had great potential in applications of forest monitoring.

Sterba (2008) and Motz et al. (2010) believe that it is more professionally optimal and (financially) cost-effective to collect additional data necessary for the assessment of spatial structure along with the regular inventory, than to do it separately. Also, given that in recent decades, more and more emphasis has shifted from stands to regional and national forest inventories (Gabler and Schadauer, 2007; Lanz et al. 2010), it is necessary that the data collection for the assessment of spatial structure be defined at this level, as well.

\section{Conclusions}

Based on the conducted research, the most important conclusions that were drawn are as follows:

- At the stand level and at the level of the whole sample, there are no statistically significant mean differences in all five indices obtained by different types of sampling.

- However, using different sampling types, a weak connection was determined through the assessment of most indices at the level of sample plots, especially indices describing the diversity of tree positions (uniform angle index and mean directional index) and indices of DBH dominance. For precise assessment of these indices when using a circular fixed radius plot of 5 ares, it is necessary to use only plus sampling during the data collection.

- For the assessment of species mingling and DBH differentiation at the level of sample plots, a strong connection was determined between different sampling types. However, even in a strong connection, there was a large deviation in certain sample plots. Conditionally, minus sampling with the edge correction buffer zone and modified cluster sampling can be used for these indices, but with less accuracy compared to plus sampling.

- Minus sampling with the edge correction NN1 is not practical for use on sample plots of this size in beech forests in Serbia.

- The general conclusion is that for the purpose of a comprehensive assessment of all aspects of spatial structure (diversity of tree positions, tree species diversity and diversity of tree 
dimensions) in the regular forest inventory in beech forests in Serbia, it is only correct to use plus sampling.

\section{Acknowledgments}

The paper is funded by the Ministry of Education, Science and Technological Development of the Republic of Serbia No.: 451-03-9/2021-14/200197.

\section{References}

1. Albert, M., Gadow, K.V. (1998): Assessing biodiversity with new neighborhood-based parameters. In: Iaumonier, Y., King, B., Legg, C., Rennolls, K. (eds). Data management and modelling using remote sensing and GIS for tropical forest land inventory. Proceedings of the FIMP-INTAG International Conference, 26-29 October 1998, Jakarta, Indonesia. pp. 433-445.

2. Bitterlich, W. (1984): The relascope idea: relative measurements in forestry. Commonwealth Agricultural Bureaux, London.

3. Bravo-Oviedo, A., Pretzsch, H., Ammer, C., Andenmatten, E., Barbati, A., Barreiro, S., Brang, P., Bravo, F., Coll, L., Corona, P., den Ouden, J., Ducey, M. J., Forrester, D..I., Giergiczny, M, Jacobsen, J. B., Lesinski, J., Löf, M., Mason, W. L., Matovic, B., Metslaid, M., Morneau, F., Motiejunaite, J., O'Reilly, C., Pach, M., Ponette, Q., del Rio, M., Short, I., Skovsgaard, J. P., Soliño, M., Spathelf, P., Sterba, H., Stojanovic, D., Strelcova, K., Svoboda, M., Verheyen, K., von Lüpke, N., Zlatanov, T. (2014): European Mixed Forests: definition and research perspectives. Forest Systems 23(3): 518-533.

4. Clark, P.J., Evans, F.C. (1954): Distance to nearest neighbor as a measure of spatial relationschips in populations. Ecology 35: 445-453.

5. Corral Rivas, J.J., Wehenkel, C., Castellanos Bocaz, H. A., Vargas Larreta, B., Dieguez Aranda, U. (2010): A permutation test of spatial randomness: application to nearest neighbour indices in forest stands. Journal of Forest Research 15: 218-225.

6. Dale, M.R.T. (1999): Spatial Pattern Analysis in Plant Ecology. Cambridge University Press, Cambridge.

7. Diggle, P. J. (2003): Statistical Analysis of Spatial Point Patterns. $2^{\text {nd }}$ ed. Arnold, London.

8. Donnelly, K. (1978): Simulation to determine the variance and edge effect of total nearest neighbour distance. In: Hodder, I.R. (ed). Simulation methods in archeology. Cambridge University Press, London. pp. 91-95.

9. Fueldner, K. (1995): Strukturbeschreibung von Buchen-Edellaubholz Mischwaeldern. Dissertation, Fakultaet fuer Forstwissenschaften und Waldoekologie, Georg-AugustUniversitaet Goettingen. Cuvillier, Goettingen.

10. Fueldner, K. (1996): Die Strukturelle Vierergruppe - ein Stichprobenverfahren zur Erfassung von Strukturparametern in Wäldern. In: Beiträge zur Waldinventur. Cuvillier Verlag, Göttingen: S. 13-30.

11. Gabler, K., Schadauer, K. (2007): Some approaches and designs of sample-based National Forest Inventories. Austrian Journal of Forest Science 124: 105-133.

12. Gadow, V.K,. Hui Y.G., Albert M. (1998): Das Winkelmaß - ein Strukturparameter zur Beschreibung der Individualverteilung in Waldbeständen. Centralblatt für das gesamte Forstwesen 115(1): 1-10.

13. Gadow, V.K. (1999): Waldstruktur und Diversität. Allgemeine Forst und Jagdzeitung 170: 117122.

14. Gadow, K., Nagel, J. and Saborowski, J. (2002): Continuous Cover Forestry. Assessment, Analysis, Scenarios. Kluwer, Dordrecht.

15. Gadow, V.K. (2005): Fosrteinrichtung. Analyse und Entwurf der Waldentwicklung. Fak. f. Forstw. u. Waldoekol. Goettingen. 
16. Gignoux, J., Duby, C., Barot, S. (1999): Comparing the performances of Diggle's test of spatial randomness for small samples with or without edge effect correction: application to ecological data. Biometrics 55: 156-164.

17. Gleichmar, W., Gerold D. (1998): Indizes zur Charakterisierung der horizontalen Baumverteilung. Forstwissenschaftliches Centralblatt 117: 69-80.

18. Hanisch K.H. (1984): Some remarks on estimators of the distribution function of nearestneighbour distance in stationary spatial point patterns. Mathematische forschung und Statistik - Statistics 15: 409-412.

19. Hui, G.Y., Albert, M., Gadow, V. K. (1998): Das Umgebungsmaß als Parameter zur Nachbildung von bestandesstrukturen. Forstwissenschaftliches Centralblatt 117 (1): 258-266.

20. Hui, G. Y., von Gadow K. (2002): Das Winkelmaß. Allgemeine Forst- und Jagdzeitung 173 (10): 173-177.

21. Hui, G.Y., Albert, M. (2004): Stichprobensimulationen zur Schätzung nachbarschaftsbezogener Strukturparameter in Waldbeständen. Allgemeine Forst- und Jagdzeitung 175 (10-11): 199-209.

22. Illian, J., Penttinen, A., Stoyan, H., Stoyan, D. (2008): Statistical Analysis and Modelling of Spatial Point Patterns. John Wiley \& Sons, Chichester.

23. Kint, V., DeWulf, R., Noel, L. (2004): Evaluation of sampling methods for the estimation of structural indices in forest stands. Ecological Modeling 180: 461-476.

24. Krebs, Ch.J. (1999): Ecological methodology, 2nd ed. Addison Wesley Longman, Inc., Menlo Park, CA.

25. Lanz, A., Brandli, U.-B., Brassel, P., Ginzler, C., Kaufmann, E., Thurig, E. (2010): Switzerland. In: Tomppo, E., Gschwantner, T., Lawrence, M., McRoberts, R.E. (eds.). National forest inventories. pathways for common reporting. Springer, Berlin and Heidelberg. pp. 555-565.

26. Lilleleht, A., Sims, A., Pommerening, A. (2014): Spatial forest structure reconstruction as a strategy for mitigating edge-bias in circular monitoring plots. Forest Ecology and Management, 316: 47-53.

27. Matović, B. (2012): Odnosi strukture, specijskog i ekosistemskog diverziteta visokih bukovih šuma Srbije. Doktorska disertacija, Biološki fakultet Univerziteta u Beogradu, Beograd, Srbija.

28. Matović, B., Koprivica, M., Kisin, B., Stojanović, D., Kneginjić, I., Stjepanović, S. (2018a): Comparison of stand structure in managed and virgin european beech forests in Serbia. Šumarski list 142(1/2): 47-57.

29. Matović, B., Stojanović, D., Kesić, L., Stjepanović, S. (2018b): Uticaj klime na rast i vitalnost smrče na Kopaoniku. Topola 201-202: 99-116.

30. Mlinšek, D. (1996): From clear-cutting to close-to-nature silviculture system. International Union of Forest Research Organisations. IUFRO News 25, 6-8.

31. Motz, K., Sterba, H., Pommerening, A. (2010): Sampling measures of tree diversity. Forest Ecology and Management 260: 1985-1996.

32. Pielou E.C. (1977): Mathematical Ecology. John Wiley \& Sons, New York.

33. Pommerening, A. (2002): Approaches to quantifying forest structures. Forestry 75(3): 305-324.

34. Pommerening, A., S.T. Murphy, 2004: A review of the history, definitions and methods of continuous cover forestry with special attention to afforestation and restocking. Forestry 77(1): 27-44.

35. Pommerening, A., Stoyan, D. (2006): Edge-correction needs in estimating indices of spatial forest structure. Canadian Journal of Forest Research 36: 1723-1739.

36. Pommerening, A. (2006a): Crancod, a program for the analysis and reconstruction of spatial forest structure. Version 1.3. University of Wales Bangor.

37. Pommerening, A., Stoyan, D. (2008): Reconstructing spatial tree point patterns from nearest neighbour summary statistics measured in small subwindows. Canadian Journal of Forest Research 38: 1110-1122.

38. Pretzsch, H., del Río, M., Ammer, Ch., Avdagic, A., Barbeito, I., Bielak, K., Brazaitis, G., Coll, L., Dirnberger, G., Drössler, L., Fabrika, M., Forrester, D.I., Godvod, K., Heym, M., 
Hurt, V., Kurylyak, V., Löf, M., Lombardi, F., Matović, B., Mohren, F., Motta, R., den Ouden, J., Pach, M., Ponette, Q., Schütze, G., Schweig, J., Skrzyszewski, J., Sramek, V., Sterba, H., Stojanović, D., Svoboda, M., Vanhellemont, M., Verheyen, K., Wellhausen, K., Zlatanov, T., Bravo-Oviedo, A. (2015): Growth and yield of mixed versus pure stands of Scots pine (Pinus sylvestris L.) and European beech (Fagus sylvatica L.) analysed along a productivity gradient through Europe. European Journal of Forest Research 134: 927-947.

39. Prodan, M. (1968): Punktstichprobe fuer die Forsteinrichtung. Forst- und Holzwirt 23: 225-226.

40. Radtke, P.J., Burkhart, H.W. (1998): A comparison of methods for edge-bias compensation. Canadian Journal of Forest Research 28:(6) 942-945.

41. Staupendahl, K. (2008): Die modifizierte 6-Baum-Stichprobe - ein geeignetes Verfahren zur Erfassung von Waldbeständen. Allgemeine Forst- und Jagdzeitung 179: 21-33.

42. Sterba, H. (2008): Diversity indices based on angle count sampling and their interrelationships when used in forest inventories. Forestry 81: 587-597.

43. Stoyan, D., Stoyan, S. (1994): Fractals, random shapes and point fields. Methods of geometrical statistics. John Wiley \& Sons, Chichester, U.K.

44. Tomppo, E. (1986): Models and methods for analyzing spatial patterns of trees. Communicationes Instituti Forestalis Fenniae, No. 138. 